\title{
STUDI EKSPERIMEN FINISHING PERHIASAN KUNINGAN DENGAN PERPADUAN ELEKTROPLATING DAN PATINASI
}

Febrian Wisnu $\mathrm{Adi}^{1}$ (wisnu_adi@yahoo.com, Jurusan Kriya Fakultas Seni Rupa Institut Seni Indonesia Yogyakarta)

\begin{abstract}
Finishing Research The combination of Patina and electroplating has been carried out according to the research target, which has been able to identify metal materials, especially brass and copper. Bronze and copper Patenting techniques with various jewelry forms. The form of jewelry created amongst other things: bracelets, pendants, jewelry earrings are made with solder technique, tatah, and saws. Before the author experiment and apply patina and electroplating as the main finishing on jewelry on the work of creation. The author first conducted patina and electroplating tests to brass and copper plates with size $2 \times 3 \mathrm{~cm}$. The process and results of this research experiment is the answer and the first step which has successfully conducted various scientific experiments with found patina finishing formula with the ideal chemical mixing composition. Research on patina and electroplating experiments can be a contribution to the progress of finishing. Patina finishing research is preferred in brass and copper.Finishing is the finishing touch of a product with a better purpose, such as increasing the quality of the ingredients, increasing the decorative value, increasing the aesthetic value of a product, following the latest design trends, and can increase the selling value of a product. This research is a new research that has not been there before with the method of merging patina and electroplating techniques will be a trend finishing and as a pioneer finishing on jewelry with brass and copper.
\end{abstract}

Keywords: jewelry finishing experiment, patination finishing, finishing electroplating

\section{ABSTRAK}

Percobaah finishing kombinasi patina dan electroplating telah dilakukan sesuai dengan target penelitian, yang telah mampu mengidentifikasi bahan logam, khususnya kuningan dan tembaga. Teknik Paten Perunggu dan Tembaga dengan berbagai bentuk perhiasan. Bentuk perhiasan yang dibuat antara lain: gelang, liontin, anting perhiasan dibuat dengan teknik solder, tatah, dan gergaji. Sebelum penulis bereksperimen dan menerapkan patina dan pelapisan sebagai finishing utama pada perhiasan pada karya penciptaan. Penulis pertama kali melakukan tes patina dan elektroplating untuk pelat kuningan dan tembaga dengan ukuran $2 \times 3 \mathrm{~cm}$. Proses dan hasil percobaan penelitian ini adalah jawaban dan langkah pertama yang berhasil melakukan berbagai percobaan ilmiah dengan menemukan formula finishing patina dengan komposisi pencampuran kimia yang ideal. Penelitian tentang percobaan patina dan elektroplating dapat menjadi kontribusi bagi kemajuan penyelesaian. Penelitian finishing Patina lebih disukai di kuningan dan tembaga. Finishing adalah sentuhan akhir dari produk dengan tujuan yang lebih baik, seperti meningkatkan kualitas bahan, meningkatkan nilai dekoratif, meningkatkan nilai estetika suatu produk, mengikuti tren desain terbaru, dan dapat meningkatkan nilai jual suatu produk. Penelitian ini adalah penelitian baru yang belum pernah ada sebelumnya dengan metode penggabungan patina dan teknik elektroplating akan menjadi tren finishing dan sebagai pelopor finishing pada perhiasan dengan kuningan dan tembaga.

Kata kunci: percobaan finishing perhiasan, finishing patinasi, finishing electroplating 


\section{PENDAHULUAN}

Proses finishing adalah pekerjaan tahap sentuhan akhir dari suatu proses pembuatan produk fungsional maupun nonfungsional. Tujuan finishing untuk logam (metal finish) adalah suatu proses pelapisan akhir pada permukaan logam atau material lain yang berbahan dasar logam dengan tujuan untuk meningkatkan nilai estetika, melindungi permukaan logam dari kerusakan, memberi lapisan yang mudah untuk pemeliharaan atau perawatan.

Mengenal tentang pelapisan logam (elektroplating) adalah elektrodeposisi pelapis atau coating melekat pada elektroda untuk menjaga substrat dengan memberikan permukaan sifat dan dimensi berbeda daripada logam basisnya tersebut atau teknik finishing, dengan cara melapis logam yang mudah berkarat (korosi) dengan logam yang tahan terhadap korosi dengan teknik listrik dan kimia. Sedangkan di masyarakat Indonesia sendiri teknik untuk pelapisan logam sangat akrab dengan nama teknik penyepuhan (Hartomo, 1992: I).

Logam sendiri terbagi menjadi dua, yaitu logam fero dan logam nonfero. Logam fero merupakan jenis logam yang sifatnya kerasakan tetapi logam ini tidak tahan terhadap korosi atau karat, seperti baja dan besi. Logam nonfero adalah logam yang tahan terhadap korosi tetapi sifatnya lembek atau lunak, seperti emas, perak, timah, dan tembaga. Di antara logam nonfero yang dikategorikan logam mulia, yaitu: emas, platina, perak, logam itu semua termasuk logam yang lunak, kecuali platina logam ini paling keras bahkan kekerasannya melebihi baja.

Pada zaman dahulu sebelum ditemukan elektroplating dan penyepuhan untuk menghindari korosi pada logam, penggabungan logam seperti tembaga dengan timah menjadi perunggu, tembaga dengan seng menjadi kuningan selain untuk tahan terhadap korosi juga menambah keindahan warna (Weretime, 1973: 875). Di antara campuran logam di atas perunggu adalah logam campuran yang tertua yang telah digunakan manusia (Brick, 1977: 180). Dengan berkembangnya zaman maka ditemukan teknik penyepuhan yang lebih modern menjadi metode yang lebih praktis, yakni elektroplating, penyepuhan dengan proses listrik dan kimia yang menjadikan logam tahan terhadap korosi.

Pelapisan logam merupakan bidang keilmuan yang menjadi salah satu penerapan teknologi elektro kimia. Kaitannya erat sekali dengan iptek bahan, kimia permukaan, kimia fisik, sampai keteknikannya. Aneka logam dapat di-plating. Berbagai logam tersebut dikelompokan atas lima golongan: coating "tumbal", coating dekoratif-protektif, coating logam rekayasa, logam-logam jarang pakai, serta berbagai jenis alloy. Semua itu masingmasing mempunyai ciri khas, baik keunggulan maupun kelemahannya.

a. Pelapis "tumbal" bahan dasarnya adalah seng dan kadmium biasanya digunakan untuk melindungi substrat misalnya besi atau baja supaya mengkilat dan tahan terhadap garam dan oksidasi.

b. Pelapis dekoratif-protektif khalayak ramai sudah lazim menggunakan istilah vernikel, vercrom, dan semacamnya, pelapisan nikel, krom. Pelapisan ini digunakan untuk melapis perabot rumah tangga, alat olah raga, alat tulis, sepeda, dan lainnya.

c. Pelapis rekayasa adalah logam yang dilapis dengan emas, perak supaya diambil dari segi keindahanya dan harganya.

d. Logam jarang pakai seperti besi dan baja, karena sifatnya yang mudah terkorosi dan jarang sekali di-plating karena logam ini kebanyakan untuk konstruksi bangunan.

e. Plating alloy adalah logam yang untuk melapis paduan elektroplating dari tembaga, timah, seng, nikel.

Mengenal tentang patina memang teknik finishing yang satu ini masih sangat awam didengar oleh perajin logam dalam dunia finishing di Indonesia dikarenakan teknik finishing patina diperlukan ketelitian dan ketelatenan dalam bereksperimen pada sentuhan akhir terhadap suatu produk logam berupa benda fungsional maupun 
nonfungsional. Arti dari patina sendiri adalah istilah dari membuat logam menjadi teroksidasi dan terkorosi dengan memperhatikan reaksi kimia yang diinginkan, sehingga menimbulkan efek-efek warna yang bisa dikehendaki yang mengacu pada lapisan korosi yang berwarna biru-hijau yang berkembang pada permukaan tembaga dan kuningan bila terkena senyawa sulfur dan oksida. Tembaga mengalami proses oksidasi biasa disebabkan oleh reaksi alam atau akibat campur tangan manusia, sehingga tembaga dapat mengalami oksidasi dan mengalami perubahan warna dari warna merah menjadai warna keemasan, biru, dan hijau. Reaksi ini terjadi pada tembaga yang mempunyai kadar masih murni.

Reaksi kimia yang menghasilkan patina terjadi disebabkan oleh film konversi sulfida yg mengandung tembaga, dan tembaga berkembang dengan oksida tembaga pada logam. Dengan demikian, permukaan tembaga akan menjadi gelap. Dengan reaksi sulfur dan oksida, mengonversi film sulfida tembaga sulfat yang menjadikan warna biru khas. Evolusi dan warna patina yang pada akhirnya ditentukan oleh sejumlah variabel termasuk suhu, lama paparan, kelembaban, lingkungan, serta reaksi kimia dan kondisi permukaan tembaga. Namun, secara umum, evolusi patina biru-hijau di lingkungan yang berbeda dipengaruhi oleh tempat dan kondisi di sekitarnya dengan perkiraan sebagai berikut: lingkungan air garam: 7-9 tahun, lingkungan industri: 5-8 tahun, lingkungan perkotaan: 10-14 tahun lingkungan yang bersih: hingga 30 tahun (https://en.wikipedia.org/wiki/Patina).

\section{Mengenal Finishing Patinasi dan Elektroplating}

Menentukan jenis bahan yang dipatina dan di-elektroplating perlu melihat dan menentukan hasil seperti apakah yang diinginkan. Dengan pemilihan bahan yang menjadi prioritas dalam finishing patina pada produk logam dilihat dari : (1) keawetan, (2) estetika, (3) kemudahan aplikasi, (4) biaya, atau (5) lingkungan. Pemilihan bahan sangat menentukan dari kualitas hasil penelitian.
Pada awal penelitian patinasi, penulis memilih logam kuningan sebagai bahan penelitian teknik finishing patina. Dalam perjalanan penelitian penulis menambahkan bahan tembaga sebagai bahan tambahan dalam penelitian untuk pembanding hasil dari suatu kualitas produk kuningan dan tembaga, yang dapat dijadikan perhiasan yang memiliki nilai dari segi keamanan dan estetika dari perhiasan tersebut.

\section{Sifat dan Kegunaan Kuningan}

Kuningan adalah logam yang merupakan campuran dari tembaga $(\mathrm{Cu})$ dan seng $(Z n)$. Tembaga merupakan komponen utama dari kuningan, dan kuningan biasanya diklasifikasikan sebagai paduan tembaga. Warna kuningan bervariasi dari coklat kemerahan gelap hingga ke cahaya kuning keperakan tergantung pada jumlah kadar seng. Seng lebih banyak memengaruhi warna kuningan tersebut. Kuningan lebih kuat dan lebih keras dari pada tembaga, tetapi tidak sekuat atau sekeras baja. Kuningan sangat mudah dibentuk ke dalam berbagai gaya, ebuah konduktor panas yang baik, dan umumnya tahan terhadap korosi dari air garam. Karena sifat-sifat tersebut kuningan kebanyakan digunakan untuk membuat pipa, tabung, sekrup, alat musik, dan aplikasi kapal laut (http://erepo.unud.ac.id).

\section{Sifat dan Kegunaan Tembaga}

Tembaga adalah unsur kimia dengan nomor atom 29 dan nomor massa 63,54, merupakan unsur logam dengan warna kemerahan. Unsur ini mempunyai titik lebur $1.803^{\circ}$ Celcius dan titik didih $2.595^{\circ} \mathrm{C}$, dikenal sejak zaman prasejarah. Tembaga sangat langka dan jarang sekali diperoleh dalam bentuk murni. Mudah didapat dari berbagai senyawa dan mineral. Penggunaan tembaga yaitu dalam bentuk logam merupakan paduan penting dalam bentuk kuningan, perunggu, serta campuran emas dan perak. Banyak digunakan dalam pembuatan pelat, alat-alat listrik, pipa, kawat, pematrian, uang logam, alat-alat dapur, dan industri. Senyawa tembaga juga digunakan dalam kimia analitik dan penjernihan air, sebagai unsur dalam 
insektida, cat, obat-obatan dan pigmen. Kegunaan biologis untuk runutan dalam organism hidup dan merupakan unsur penting dalam darah binatang berkulit keras (http://ferdymp.blogspot.co.id).

Kebanyakan tembaga digunakan untuk peralatan listrik (60\%); konstruksi, seperti atap dan pipa (20\%); mesin industri, seperti penukar panas (15\%); dan paduan logam (5\%). Paduan tembaga yang sudah dikenal sejak lama adalah perunggu; kuningan (paduan tembaga-seng); paduan tembagatimah-seng, yang cukup kuat untuk membuat senjata dan meriam; paduan tembaga dan nikel, yang dikenal sebagai cupronickel dan digunakan sebagai pembuat mata uang logam.Tembaga ideal digunakan sebagai kabel jaringan listrik karena mudah ditangani, dapat ditarik menjadi kawat halus dan memiliki konduktivitas listrik tinggi (www.amazine.co).

\section{Proses Pembersihan Plat Kuningan danTembaga}

Langkah-langkah dalam pembersihan logam tembaga dari kotoran, minyak, dan karat lembaran logam kuningan dan tembaga yang sudah dipotong dibersihkan dengan cara diamplas terlebih dahulu dengan tujuan kotoran dan kerak yang menempel terlepas dari logam tersebut. Proses pembersihan logam kuningan dan tembaga berikutnya dengan menggunakan cairan air keras $\mathrm{H}_{2} \mathrm{SO}_{4}$ (asam sulfat). Selain $\mathrm{H} 2 \mathrm{SO} 4$ bisa diganti dengan Vicxal pembersih lantai. Perbandingan komposisi dalam penggunaan Vicxal adalah $100 \mathrm{ml}$ Vicxal dicampur dengan air sebanyak $1000 \mathrm{ml}$. Proses pembersihan pelat kuningan dan tembaga direndam dalam larutan Vicxal selama 3 menit lalu diangkat dan disikat dengan sikat kuningan. Setelah tahapan tahapan pembersihan selesai plat kuningan dan tembaga tersebut siap untuk dipatinasi ataupun di-elektroplating dengan hasil yang maksimal.

\section{Teknik Elektroplating Perak}

Tahapan elektroplating sebagai berikut: potong pelat tembaga dimasukkan ke dalam cairan kimia $\mathrm{H} 2 \mathrm{SO} 4$ sebanyak $100 \mathrm{ml}$ dicampur dengan air $1000 \mathrm{ml}$. Proses ini mempunyai tujuan untuk menghilangkan kotoran yang melekat pada lapisan tembaga dengan dibantu disikat menggunakan sikat kuningan. Tahapan selanjutnya memasukkan pelat tembaga tersebut ke dalam cairan kimia dengan komposisi 1 gram perak yang dicairkan dimasukkan ke dalam 1000 ml aquadas yang sudah diberi 200 gram potasium sianida.

Tahapan dalam plating perak sebagai berikut: memasukkan pelat tembaga yang sudah bersih ke dalam cairan perak yang dialiri menggunakan arus listrik DC dengan arus 6-12 volt dengan tahapan lempeng kunigan kuningan dan tembaga sebagai anoda dialiri arus (-) dan perak sebagai katoda bahan pelapis terhadap kuningan dan tembaga dialiri arus (+).

\section{Pewarnaan dengan Teknik Patinasi}

Proses pewarnaan dengan teknik patinasi pada logam tembaga menggunakan 5 bahan utama antara lain: amonia, baking soda, garam, cuka, belerang, dan gula. Masing-masing bahan tersebut mempunyai kegunaan yang berbeda-beda. (1) Cairan amonia mempunyai fungsi sebagai pengurai bahan-bahan kimia dan mempercepat proses oksidasi dalam pembentukan warna patinasi. (2) Baking soda berbentuk serbuk halus berfungsi untuk menguatkan konsentrasi pembentukan warna kebiruan. (3) Gula berfungsi untuk mengancing atau mengikat warna. (4) Garam berfungsi membentuk warna menjadi kehijauan dan memunculkan efek karat. Garam sangat sangat berperan dalam memengaruhi hasil dari proses patinasi. Sedangkan untuk garam yang berbentuk kasar memberikan hasil patinasi dengan tekstur kasar yang berbentuk blok besar. (5) Cuka murni memberikan hasil 
patinasi berwarna hijau tua atau kebiruan warna hijau atau biru terang maupun tua muncul tergantung dari konsentrasi komposisi banyak sedikitnya cuka dan penambahan baking soda.

Penulis dalam bereksperimen juga menggunakan teknik bakar untuk finishing patinasi dengan menggunakan tambahan bahan tawas dan belerang yang dimasak di atas kompor hingga menjadi gumpalan cokelat kristal kemudian kristal tersebut dihancurkan dengan cara ditumbuk menggunakan tumbukan logam hingga menjadi serbuk halus. Hasil dari tepung tersebut dijadikan bahan untuk finishing.

Tabel 1. Hasil dari Pewarnaan Patinasi yang Dilakukan pada Pelat Kuningan dan Tembaga

\begin{tabular}{|l|l|}
\hline $\begin{array}{l}\text { Percobaan Komposisi } \\
\text { Perpaduan Amonia + } \\
\text { Baking Soda + Garam }\end{array}$ \\
\hline $\begin{array}{l}\text { Percobaan Komposisi } \\
\text { Perpaduan Amonia + } \\
\text { Baking Soda + Cuka }\end{array}$ \\
$\begin{array}{l}\text { Percobaan Komposisi } \\
\text { Baking Soda + Garam + } \\
\text { Cuka }\end{array}$ \\
\hline
\end{tabular}

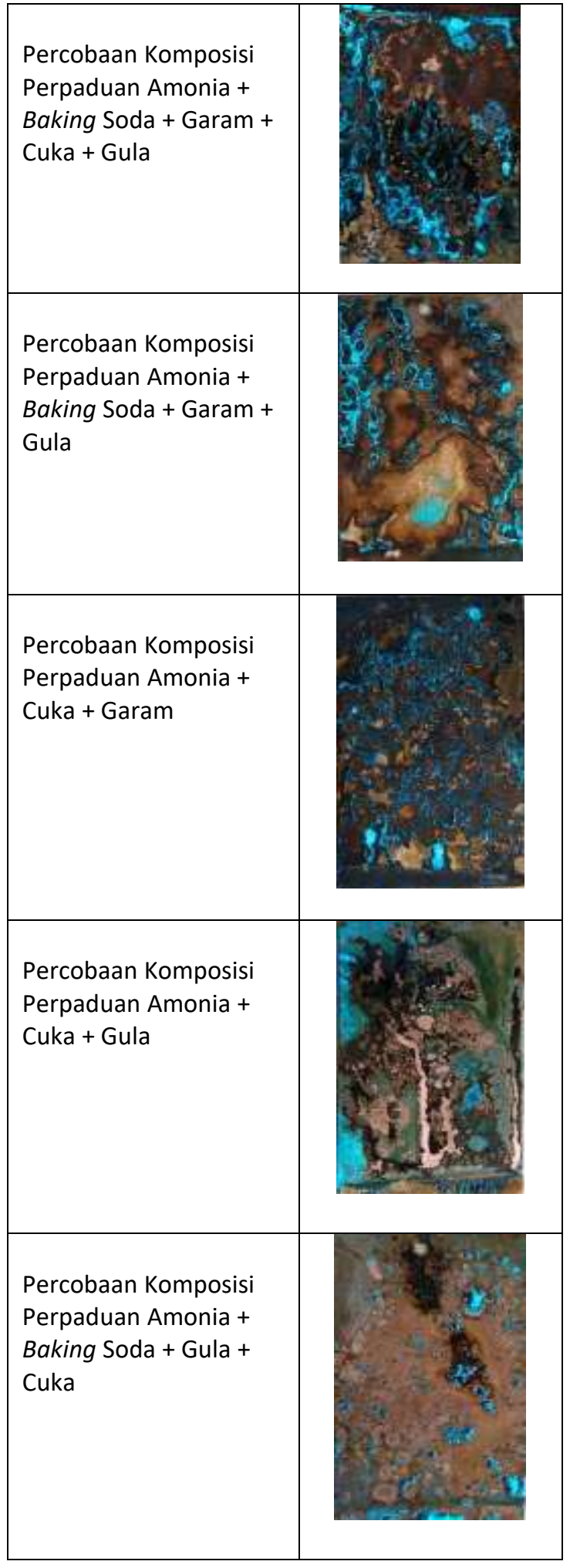




\begin{tabular}{|l|l|}
\hline Percobaan Komposisi \\
Perpaduan Amonia + \\
Baking soda
\end{tabular}

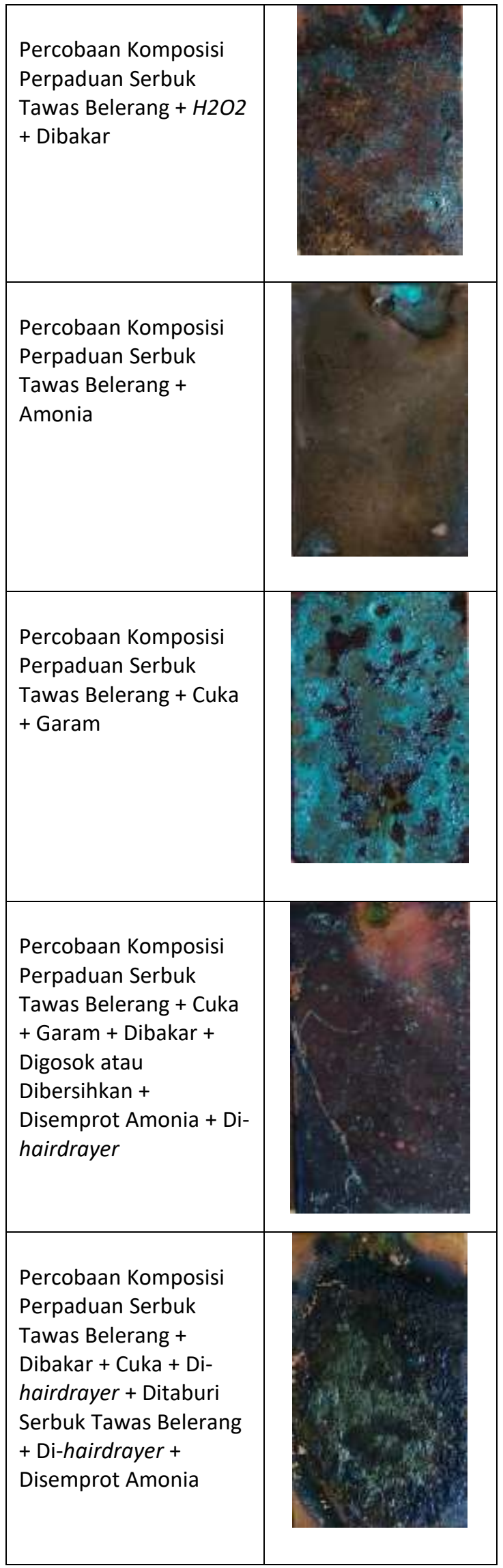


Tabel 2. Hasil Eksperimen Perpaduan Finishing Patina dan Elektroplating

Hasil Finishing
Elektroplating
Emas, Perak,
dan Warna
Posh

\begin{tabular}{|l|}
\hline Hasil Finishing \\
Elektroplating \\
Perak dan \\
Warna Posh \\
Hasil Patinasi \\
dengan Bahan \\
Finishing \\
Amonia, \\
Garam, Baking \\
Soda \\
\\
Hasil Finishing \\
Elektroplating \\
Perak dan Hasil \\
Patinasi dengan \\
Bahan Finishing \\
Amonia, \\
Garam, Baking \\
Soda, Cuka, \\
Saus
\end{tabular}

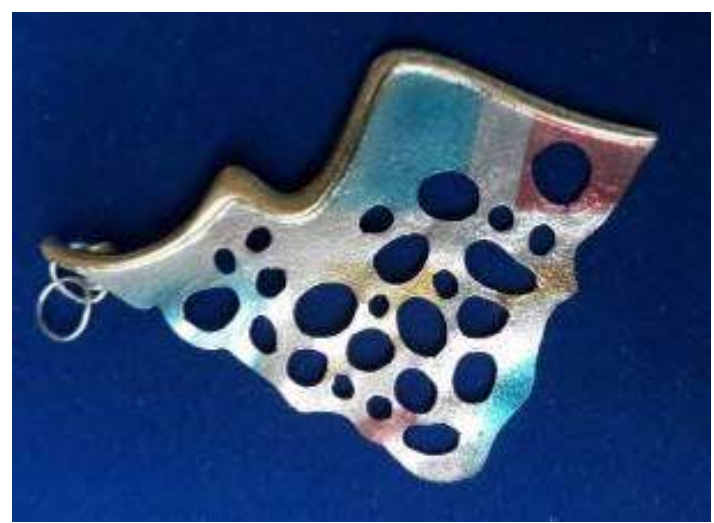

Gambar 1. Hasil Finishing Elektroplating Emas, Perak, dan Warna Posh

\section{PENUTUP}

Penelitian finishing perpaduan patina dan elektroplating telah dilaksanakan sesuai target penelitian. Hasinya telah dapat mengidentifikasi bahan logam terutama logam kuningan dan tembaga. Teknik patinasi kuningan dan tembaga dipraktikkan dengan menghasilkan berbagai bentuk perhiasan.

Bentuk perhiasan yang diciptakan antara lain: gelang, liontin, anting. Perhiasan tersebut dibuat dengan teknik patri, tatah, dan gergaji. Sebelum penulis bereksperimen 
dan mengaplikasikan patina dan elektroplating sebagai finishing utama pada perhiasan pada karya penciptaan, penulis terlebih dahulu melakukan tes patina dan elektroplating pada lempengan-lempengan kuningan dan tembaga dengan ukuran $2 \times 3$ $\mathrm{cm}$. Proses dan hasil dari percobaan penelitian ini merupakan jawaban dan langkah awal yang akhirnya telah berhasil melakukan berbagai percobaan ilmiah dengan ditemukan formula finishing patina dengan komposisi percampuran bahan kimia yang ideal. Penelitian tentang eksperimen patina dan elektroplating dapat menjadi sumbangan kepada kemajuan ilmu finishing. Penelitian finishing patina diutamakan pada logam kuningan dan tembaga.

Finishing merupakan sentuhan akhir terhadap suatu produk dengan tujuan yang lebih baik, seperti meningkatkan nilai mutu bahan, meningkatkan nilai dekoratif, meningkatkan nilai estetika pada suatu produk, mengikuti tren desain terkini, dan dapat meningkatkan nilai jual suatu produk. Penelitian ini merupakan penelitian yang bersifat baru yang belum ada sebelumnya dengan metode penggabungan teknik patina dan elektroplating yang akan menjadi tren finishing dan sebagai pelopor finishing pada perhiasan dengan bahan kuningan dan tembaga.

Penulis dalam proses bereksperimen patina tidak menemukan kendala dalam proses pewarnaan logam kuningan maupun tembaga, namun kendala muncul pada pembuatan perhiasan yang berbahan kuningan. Kendala tersebut berupa kesulitan dalam proses penyatuan antara kuningan yang dipatri dengan kuningan maupun kuningan dengan tembaga. Dengan demikian perhiasan yang dibuat penulis 70 $\%$ menggunakan tembaga dan $30 \%$ menggunakan campuran kuningan. Penulis menarik kesimpulan bahwa material tembaga lebih mudah dalam pengerjaan, dalam pembuatan perhiasan, maupun dalam pewarnaan dengan patina.

\section{Daftar Pustaka}

Brick, Robert M, Pense, Alan M, and Gordon, Robert B. 1977. Structure Properties of Engineering Materials. New York: MacGraw-Hill.

Gustami, SP. 2004. Proses Penciptaan Seni Kriya: Untaian Metodelogis. Yogyakarta: Program Pascasarjana Institut Seni Indonesia Yogyakarta.

Haryono, Timbul. 2001. Logam dan Peradaban Manusia. Yogyakarta: Philosophy Press.

Wertime. 1973. Beginnings of Metallurgy: $A$ New Lock.. Science, 182, 875-887.

https://en.wikipedia.org/wiki/Patina 